\title{
Direct Marketing: An Imperative In Building Effective Comunication In Hospitality Enterprises
}

\author{
Fatos Ukaj, Associate Prof. \\ University “Hasan Prishtina”, Economic Faculty, Pristina, Kosovo
}

doi: 10.19044/esj.2016.v12n10p240 URL:http://dx.doi.org/10.19044/esj.2016.v12n10p240

\begin{abstract}
The role of marketing in tourism and hospitality cannot be overemphasized due to the experience of countries with a developed sector of tourism and hospitality. Marketing, which entails the communication process with clients and the market, is very important. A form of communication aimed towards the promotion of enterprises is regarded as direct marketing. Hence, this is the subject of analysis in this paper. Direct marketing supports an enterprise in establishing closer relations, understanding, and in creating loyalty among clients. Therefore, recognizing the benefits of direct marketing is a great achievement. This is because it enables the enterprise to create a good image for its service. In addition, it also helps the enterprise, in general, to increase its awareness and in achieving better results in business.
\end{abstract}

Keywords: Marketing, tourism, direct marketing, client, business

\section{Introduction}

The role and the function of marketing in our country have reached a quite satisfactory level. This level can be seen based on its application and development in businesses of different activities including the tourism, hospitality, and the public and private institutions of the Republic of Kosovo. The pillars of a complete marketing include the product, the price, place, promotion, people, the process, and physical evidence (7P), otherwise called a holistic or inclusive marketing. The use of this concept of marketing in daily business can have a significant impact in recognizing better products and the services of a particular enterprise or institution. Furthermore, it also assists in bringing closer the enterprise/institution and customers, and the clients and the general public. Consequently, the fourth element of marketing mix is promotion. Promotion is the driving force that fosters the communication of an enterprise with the general public. At the same time, it passes information, persuades, and encourages enterprise's customers/clients 
to purchase. In the frame of this communication, public relations were highlighted to have a significant impact in the promotion of the enterprise/institution. Thus, this makes it possible for the enterprise/institution to be closer to interested parties. It also helps them in their decisions to purchase. Furthermore, it helps to inform them on the current developments in the respective enterprise. Promotion entirely has to do with public communication with intention of influencing the purchase and usage of company products and services (Ukaj, 2013). Based on the definition that promotion is an organized process of communication between the manufacturer or trader and the customer, it is a mixed marketing tool with dynamic features, where the mission of communication is performed through the application of efficient methods and media for supply and demand (Jakupi, 2002). It can be distinguished based on the need for resources in performing the enterprise communication activities. Therefore, the budget for promotion appears to be a vital issue. Public relations (PR) take many forms in different enterprises/institutions. As such, it appears under many names, including public information, relations with investors, public affairs, corporate communication, and marketing or relations with customers. Public relations employ a number of tools, such as personal contacts, donations, sponsorships, foundations, and continuous information (Gunther, 2010). The techniques which are the main forms of public relations, according to Gunther, are: brochures, leaflets, speeches or contacts, and professional presentations, etc. In order to further diminish the confusion created by the presented forms, it should be pointed out, not always, that all of these forms are accurately related to public relations. However, all of them cover at least a part of what is called public relations. This paper is aimed to address the ways of communication of an enterprise/institution. This is with the main actors in the environment by whom the enterprise/institution performs its activities, the build-up of relations with customers and their future, the use of advertisement techniques, and the importance of equipping the staff with communication skills. Through data analysis, we are going to establish a picture of the role and importance, particularly, of public relations and publicity in the communications of the enterprise. By gaining knowledge, we will examine the strategies which the enterprise should use to achieve its objectives, among others, to win the loyalty of customers.

\section{Tourism and Hospitality: Specifics of their Activities}

Tourism as an activity has its own specifics. Therefore, in the frame of its service activities, it is seen as a specific sector. Also, it is distinguished also by the characteristics of its offer, which is often regarded as a product or service. This product or service, however, has distinguished features such as tangible, inseparable, delicate due to the inability to preserve, and is instantly 
consumable. Therefore, this is because the provision and consumption of this product is done in real time (Mak, 2004; Ukaj, 2014). Another feature of tourism and hospitality is that major investment of capital is required, and it has a great sensitivity to environmental factors. The touristic offer is not elastic, but it is homogeneous and static. In addition, it is characterized by the inability to respond rapidly to changes in the demands of customers or tourists. Of course, this activity is guided by the market demand respectively and by the trends in the demands of customers or tourists. The demand in this sector has become more sophisticated, more selective, and more complex. This occurs, especially, when it takes into consideration the seasonal and geographic changes which affect both the supply and the demand. The key to the success of an enterprise with its own offer lies in the possibility to provide a remarkable experience to tourists (customers), and not only food and accommodation in its premises. According to Porter, an enterprise is different from its competitors if it manages to become special in an aspect that is perceived by the customer as a value (Porter, 2007). Subsequently, the perception of a customer/tourist about the tourists and hospitality enterprise is based on the offer itself. In the multitude of similar offers, the offer has its specificities which distinguish them from their competitors. Therefore, it is necessary for the enterprise to encourage innovative ideas to make the offer of the enterprise special compared to the offers of competitors. Recently, the seasonal aspect of tourism has been minimized due to the fact that more and more tourists are opting for more than one holiday during the year. Furthermore, this should become a driving force for enterprises to review their way of doing business. As a result, this paper emphasizes the mode of communication with the market and customers (tourists), in order to build a better business and achieve the objective of the market in becoming the first choice by tourists. In such a case, it is important to highlight the role of each participant in this activity starting from the enterprise, tourist associations, tourist agents, and the central and local government institutions when speaking about Kosovo as a tourist place (Ukaj, 2015). Additionally, everyone should clearly understand their role and tasks in providing satisfaction to a visitor or tourist in a tourist destination. This can be attained by focusing on innovations of the offer towards the demands which are constantly changing. One of the factors which should be seen as an innovation is the information and communication technology through an efficient information system, which in a way plays the role of a distribution channel in this sector (Ukaj, 2015). Enterprises should do it in order to maintain the positions they have reached and to make progress in creating competitive advantages. In addition, they should do everything humanly possible to retain their customers. However, this is mentioned in this paper as one of the objectives of an enterprise. 


\section{Integrated Marketing Communication with an Emphasis on Public Relations and Publicity}

There are some techniques in theory and practice which define how enterprises define the budget for the needs of communication with the public. These techniques include: everything can be handled - this is based on the assumption that the enterprise can become a failure after defining the tasks and funds for all sectors, and the remaining funds for promotion. Financing enterprise promotion based on reference - defining the budget for the upcoming year in the function of the previous period. Comparison with the competition - is applied to both small and large enterprises, where on the basis of competition, expenses for promotion are also implemented. Percentage on sales - based on the sales performance in certain periods, the amount of the budget for promotion in general is defined. Objectives and tasks - the enterprise defines the objectives and tasks for promotion and based on this, it allocated the budget for promotion (Duka \& Pano, 1999). Public relations (PR) are the activities performed through media, both traditional and new, which enables the provision of information and the publication of recent news about the enterprise, marketing brands, and activities. Public relations (PR) have been recently presented as the most powerful methods of promoting products, services, and ideas. Essentially, it provides a basis to transform the connection between the customer and the particular product of the enterprise and the media as a demand by enterprises. The purpose of public relations of an enterprise often serves to persuade the public, investors, partners, employees, and other stakeholders to maintain a certain level of good opinion about the enterprise, its management, products, or activities. Subsequently, common activities include participation in conferences, competitions to win prizes in the industry (national and international), cooperating with the press, and communication with the employees (Duka \& Pano, 1999). One of the fastest growing sectors of the American economy is direct marketing. Through direct marketing, organizations communicate directly with the targeted customers in order to generate a response and/or a transaction. In the past, this type of communication, such as direct marketing, was not considered or treated as an element of the mixed promotion. However, due to the fact that it often includes specific objectives, the budget, and specific strategies, it is seen as a component of the mixed promotion. Direct marketing is much more than direct mail, catalogues, and e-mail. It includes a range of activities, covering the database management, direct sales, telemarketing, and direct responses to the advertisements through direct mail, the internet, and various broadcasts or print media. Furthermore, it is important to recognize the difference between publicity and public relations. When a systematic organization plans and disseminates information in an effort to control and 
manage its image and the nature of publicity (positive or negative) that it receives, then we are dealing with the promotion activity known as public relations. Public relations have been defined as "the management function which evaluates public attitudes, identifies policies and procedures of an individual or organization of public interest, and executes a program of action to earn public understanding and acceptance" (Duka \& Pano, 1999). Relations with the public in general have a wider objective than publicity. As such, its aim is to create and maintain a positive image of the enterprise among its different public. Public relations use publicity, and a variety of other tools, including special publications, participation in community activities, fundraising, sponsoring special events, and various other public events, as well as activities in improving the image of the enterprise/institution in general. It has also been noticed that enterprises use advertisements as a tool to achieve the establishment of relations with the public. Traditionally, publicity and public relations have been considered more as supportive activities rather than the primary activities in the promotion process of the enterprise. However, many enterprises/institutions have begun to treat $\mathrm{PR}$ as an integral part of their marketing envisaged in their promotional strategies. Consequently, specialized agencies on PR have been treating public relations more and more as a communication tool, which could take over many of the functions of conventional advertising and marketing.

\section{Publicity}

Another important component of the promotional mix of an enterprise/institution is publicity. Publicity refers to non-personal communication with an organization, product, service, or idea by not being directly paid by the enterprise/institution. However, it can be achieved by an identified sponsorship. It usually comes in the form of news story, editorial, and information about an event organized by the enterprise/institution regarding its products and services. Same as advertisement, publicity includes non-personal communication to a mass audience. However, unlike advertisement, publicity is not paid directly by the enterprise. Efforts of the enterprise/institution to attract media coverage, as well as show a favorable story about a product or service, is achieved by recognizing the importance of this form as an influential factor in raising awareness, knowledge, perceptions, and the behavior of a customer. The enterprise/institution has little control over publicity, over what has been said, who said it, or when it has been said. As a result, in practice, publicity is rarely treated as the main component of a promotional campaign of an enterprise/institution. The techniques used to gain publicity include press releases, press conferences, features, photographs, films, video tapes, etc. When it is elaborated from the 
aspect of distinguishing element that is "indirectly paid", there is a crucial difference between publicity and advertising, personal sale and public relation. When it comes to publicity, a company does not pay for coverage in mass media, such as television or radio, but tries to make the medium interested to present a favorable story on the enterprise/institution. In this regard, it is noticed that there is an indirect payment for publicity. Therefore, the enterprise/institution must recruit permanent staff for public relations, or even hire a professional agency of PR. An advantage of publicity over other forms of promotion is its reliability. Consumers generally tend to be less skeptical towards favorable information regarding a product or service, when it comes from a source they perceive as impartial, and when it refers to the media.

\section{Public Relations Strategy}

Public relations is a form of communication management which seeks to influence the feelings, thoughts, or convictions of clients, future customers, holders, suppliers, employees and others regarding a company and its products or services (Bennet, 1995). Public relations (PR) are the management practice of disseminating information between an individual or an organization and the public (Todd, 1984). Public relations can include an organization or an individual in exposing them to their audience. Thus, this is done by using topics of public interest and news articles which deal with the enterprise, but no payment is required for those activities (Todd, 1984). Many tools such as special events, lobbying efforts, annual reports, and image management can be used by the public relations department. Nevertheless, it must be admitted that publicity often plays the most important role in such situations for the enterprise. The position of public relations within mixed marketing is seen as building strategic relations between the enterprise/institution and various segments of the public. However, this is with the aim of gaining the trust and understanding of the public, in general, and, in particular, the trust of loyal customers. Public relations support and facilitate the use of other instruments of strategic marketing. Nonetheless, these represent different instruments of communication policy, by incorporating it in the communication strategies of the enterprise or institution. Public relations put their activities more on "Corporate Identity", which in fact is the image of the company itself. The image and aspiration of how the company wants to be perceived by the interested sector of public is determined to a large degree by the stated mission of the company. An element of corporate Identity is known as "corporate design". This design introduces a company in public through creative elements of representation, such as: brand name, logo, writing, color, and design. Thus, it becomes possible for the enterprise/institution to 
be identified quickly. The presentation is accompanied by other experiences that the public have had with the enterprise/institution. Also, both are combined together to create the desired image of the company. The Public relations strategic plan includes: information as a service, favoring channels of information, awareness of staff, and demonstration in the labor market. Within an enterprise/institution, as far as PR is concerned, it can be distinguished based on the need to communicate with: the media, the involved staff and others in the enterprise, and the customers. Regarding the relations with media, the following forms were distinguished: press conferences, press releases, and press activities. While for the human relations, the following forms are distinguished: instructions for staff, bulletin board and the system of internal mail, company's magazine, letters or emails addressed to staff, work excursions, visit of the employee family members by the company, and the suggestions scheme of the employees. The main forms of relations with customers are: correspondence and telephone, publications, customer magazines, visits to factory, waiting rooms, business reports, and special service features. According to Johann Gunther, in his publication titled "Marketing", he stated that although public relations seem the same, the difference exists between enterprises, depending on the activity, the place it operates in, and the size of the enterprise. Public relations cover the development of friendly relations with organizations and products for its main public. Subsequently, this is done by using a variety of communication channels and tools. Traditionally, this means that public relations professionals will work with media representatives to build up a favorable image. This image is built through the publication of information regarding the enterprise or product. In addition, it is also built by preparing stories both for print and electronic media. However, the role of public relations today is much broader and it includes raising awareness and a favorable image for an enterprise or a client of the enterprise in the stories and articles contained in the relevant media. This is done by observing and following public comments regarding that particular enterprise and its products. Problems in managing the target market by the enterprise through PR programs such as community events and programs, threaten the image of the enterprise/institution or the product. Furthermore, our focus is oriented towards the issue on how public relations support the marketing of an enterprise/institution by building up the image of the product and the enterprise. This is often associated with elements of publicity as a promotional activity. Selection of favorable media regarding communication for an enterprise/institution or product often reaches the favorable audience. In addition, it may provide potential benefit for the position of the enterprise in the market and the public, in general. It is noticed that in large companies, relations with investors (IR) or financial relations are a specificity of PR and 
their own organizational form in the enterprise itself. Therefore, this is governed by the rules in providing specific explanatory information. In support of the image of the enterprise or the product, public relations present, not only the history of an enterprise to the general public, but it also helps in shaping the idea regarding the organization of the enterprise and its mode of operations. In order to be effective, an enterprise/institution needs to hear the opinion of their customers, and not only in providing information. Therefore, releasing a large amount of news and information with propaganda character is not sufficient in today's open society. Authors cited above in this paper also suggests that some rules regarding public relations which are considered professional and effective in terms of achieving the objectives and implementation of strategies include: establishment of communication lines, organization of information based on uniform criteria, intervene in different events, verify the presence of news regarding particular activities, and membership in associations which is directly linked to PR. Based on theory and practice, it is noticed that all effective marketing communication consists of, at least, four elements: a sender, a message, a communication channel, and a recipient (Hallensen, 1998). In practice, we have come to understand that in the frame of the communication system, we also distinguish between the elements of coding, decoding, noise-barriers, and the returning force of the information provided. In order to communicate effectively, the sender must have a clear understanding of the aim of the message, reaching to the audience, and how the public is going to interpret and comment on the message. Sometimes, the audience cannot hear clearly what the sender is trying to tell about the enterprise or its product due to "the noise" created by the competition or other environment factors. Thus, this may have an influence on contradictory opinions about their products.

\section{Conclusion}

In conclusion, accepting and applying the concept of marketing leads the enterprise/institution towards using direct marketing as an essential part of effective communication with different factors in a particular context where the activity is implemented. Therefore, direct marketing, public relations forms, and publicity have gained a special significance in communication. At the same time, they have made the enterprises change their business philosophy and approach practices to the public completely. In tourism specifically, through the application of this form, efforts are being made to maintain and develop long-term relations with the existing clients. This was better instead of the practice of running after finding new customers. This strategy has proven effective in the case of developed tourist countries. Also, it is more profitable than the previous one. Consequently, due to the "closeness to customers" through direct marketing, the enterprises 
involved in tourism and hospitality develop it by shaping their offer based on the customers' demand. Thus, it has been proved that the satisfaction of a customer increases with the purchase carried out. Also, it has a positive effect on their perception of the image of the enterprise and its products and services. However, in this activity, it is well-known that there is no obligation to keep and maintain all customers, except those who bring profit to the enterprise. It has been proven above that direct marketing and forms of communication such as public relations and publicity can help the enterprise expand its market, increase sales, increase profits, and enhance the image of the enterprise and of the particular brand. As a precondition to apply the concept of direct marketing and maintain relations with the public, there is the need to have a database of existing and potential customers, as well as the use of appropriate tools for communication.

\section{References:}

Bennet,P.A. (1995). Dictionary of marketing terms, Chicago, 1995, p.231.

Duka,A., Pano,N. (1999). Promocioni, Tiranë, p.25.

Gunther, J. (2010). Marketing, New York, p. 232.

Hallensen (1998), Global Marketing, A market-responsive approach, England, p. 516.

Jakupi,A. (2002). Bazat e Marketingut, Prishtinë, p. 331.

Porter,M.E. (2007). Konkurentska prednost-ostvarivanje i ocuvanje vrhunskih poslovnih rezultata, ASEE, Novi Sad, p. 133.

Todd,H. (1984). Managing Public Relation, Orlando, p. 6

Ukaj, F. (2013). Promotion and integrated marketing communication as a process with influence in consumer behavior, Proceddings ISSN 22328742, $\quad$ p569-574 http://www.dukagjinicollege.eu/libri3/569574_Ukaj_Fatos.pdf

Ukaj, F. (2015). Internet Marketing and Online Consumer Behavior in the case of Kosovo market, European Scientific Journal (ESJ), Vol 11, No 25 (2015), p 70-79.

Ukaj,F. (2014). Development of a Tourist Destination Based on Marketing Activities, Academic Journal of Interdisciplinary Studies, MSCER Publishing Rome-Italy, Vol 3, No 2 (2014), p 147-154.

Ukaj. (2015). Impact of International Business on Kosovo's Economic Development with Emphasis on Tourism, Mediterranean Journal of Social Sciences ,MSCER Publishing Rome-Italy, Vol 6, No 3 S2 (2015), p 35-39. 